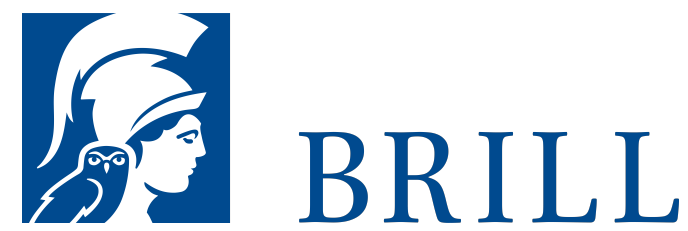

\title{
Eine Theorie der Generationengerechtigkeit
}

\author{
Author:Jörg Tremmel
}

Der Bezug auf 'unsere Pflichten gegenüber künftigen Generationen' ist eines der kraftvollsten, emotionalsten und effektivsten Argumente, das Politikern und Bürgern zur Verfügung steht. Die exakte Art und der Umfang dieser Pflichten sind allerdings unklar. Sind wir kommenden Generationen überhaupt etwas schuldig? Wenn ja, wie groß ist der Umfang unserer Pflichten? Und auf welche Ressourcen oder Güter beziehen sie sich? Dieses Buch kommt zur rechten Zeit: Es liefert die bisher genaueste ethische Landkarte für die immer wichtiger werdende Zukunfts- bzw. Generationenethik. Obwohl von bisher unerreichter Tiefe und Bandbreite - das

Literaturverzeichnis umfasst die gesamte relevante Literatur zu diesem Thema -, macht Tremmels klarer Stil das Buch zu einer leicht lesbaren und abwechslungsreichen Lektüre. Im Ergebnis schlägt dieses Buch eine Theorie der Generationengerechtigkeit vor, die nicht nur für die philosophische, sondern auch die politische Debatte neue Impulse bringen wird.

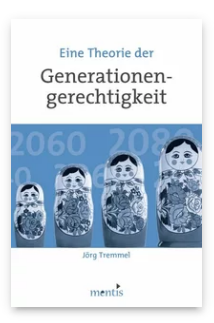

Pages: 341

Seiten

Language:

German

Subjects: 19 th \& 2oth Century

Philosophy, Philosophy

Publisher: Brill | mentis

E-Book (PDF)

Released online: og Oct 2012

ISBN: $978-3^{-}$ 95743-943-7

List price

USD $\$ 68.00$

Paperback

Publication date:

o9 Oct 2012

ISBN: 978-3-

89785-706-3

List price

USD $\$ 68.00$ 
For more information see brill.com

Order information: Order online at brill.com +44330 333 0049 | customerservices@brill.com Submission information: brill.com/authors

Titles published by Brill | Fink, Brill | mentis or Brill | Schöningh: +49(o)715413279216| brill@brocom.de 